\title{
Development of a groundwater flow model for the highly parameterized Qatar aquifers
}

\author{
Husam Musa Baalousha ${ }^{1}$
}

Received: 19 March 2016/Accepted: 21 March 2016/Published online: 2 April 2016

(C) Springer International Publishing Switzerland 2016

\begin{abstract}
Groundwater models are powerful tools for water resources management, assessment and protection. The main challenge facing model development is the calibration process, especially in large models with a high number of calibrated parameters. Qatar aquifers comprise karst limestone with lots of cavities, sinkholes and underground channels. Therefore, the aquifer is highly heterogeneous. This study presents the development of a regional scale groundwater flow model for the entire country of Qatar, with emphasis on calibration process. Pilot points approach with regularization has been utilized to calibrate the model to re-produce historical water levels representing steady state conditions. Hydraulic conductivity and natural rainfall recharge were calibrated, using historical groundwater levels from 1958. Results of the model included predevelopment water budget for the country, and estimation of natural groundwater recharge, which was found to be 65.6 million $\mathrm{m}^{3}$ per year. Calibration process also reveals that the top layer of the aquifer, and the northern part have the highest hydraulic conductivity, compared to other areas. The calibrated hydraulic conductivity values are quite variable, as it ranges from $0.1 \mathrm{~m} /$ days to more than $200 \mathrm{~m} /$ days. Results of this model can help understanding the flow regime, aquifer parameterization and design of artificial recharge scheme in Qatar.
\end{abstract}

Keywords Groundwater modelling $\cdot$ Modflow $\cdot$ Pilot points · Regularization · Qatar

Husam Musa Baalousha

baalousha@web.de

1 Qatar Environment and Energy Research Institute (QEERI), Hamad Bin Khalifa University (HBKU), PO Box 5825, Doha, Qatar

\section{Introduction}

Qatar is an arid country with limited water resources and high per capita water consumption. With rapid urbanization and population growth over the last decade, Qatar faces a great challenge regarding water security and sustainability. Qatar National Vision 2030 (General Secretariat for Development Planning 2008) identified environmental development and protection as one of four pillars of this vision. The environment pillar covers issues related to environmental protection and mitigation of climate change, in addition to adaptation to sustainable development of the country (General Secretariat for Development Planning 2008).

In the light of 2030 vision, aquifer storage and recovery was identified as one of the main country grand challenges to mitigate the adverse impact of overexploitation of Qatar aquifers and to increase national water security. Overexploitation of groundwater resources is evident in the sharp drop of water table and quality deterioration resulting from seawater intrusion (Schlumberger Water Services 2009a). The country is fully relying on desalination to meet all of its domestic and industrial water demand, which has adverse environmental impact and provides little water security. While most municipal and industrial needs are met by desalination, agriculture depends on groundwater. The Qatar General Electricity and Water Corporation (Kahramaa) has initiated several projects to increase water production from desalination and to reduce losses in the network. According to 2013 figures, the desalinated water production was 465 million $\mathrm{m}^{3}$ per year, with approximately $23 \%$ losses (The Qatar General Electricity and Water Corporation 2014). The current storage capacity of desalinated water in Qatar is 3.5 million $\mathrm{m}^{3}$, which meets the domestic demand for 2 days only. The groundwater recharge project aims at artificially storing water in the aquifer for future use. The stored water should be of 
acceptable quality and should be enough quantitatively to meet the domestic needs of the State of Qatar in case of an emergency. When completed, the recharge project will serve as a national secure water reservoir, which is not prone to contamination or quick depletion, and it will significantly increase the water security in the country.

Groundwater flow modelling is a fundamental step to understand groundwater flow regime, water budget, recharge estimation, risk assessment and stream depletion assessment (Wang et al. 2016; Baalousha 2012a, b; Rahman et al. 2004). A groundwater flow model has been developed in this study to understand the steady state conditions of the aquifers in Qatar prior development and to assess different hydrological components. It will later be used to assess establishing an artificial recharge scheme.

To have a reliable and usable model, it should be wellcalibrated. The challenges facing calibrating a regional model is the large number of uncertain parameters, which requires tedious effort. In many occasions, the calibration process is numerically unstable and the resulting solution is non-unique (Doherty et al. 2010). Coupling these challenges with lack of reliable data makes the process even more complicated. Traditionally, calibration process is done using zonation approach, where the model domain is divided into zones of various values of a parameter. This division is done based on modeller judgment and knowledge of the geology of the area of study. However, zonation approach is problematic as the change between different zones is abrupt (Doherty 2003; Anderson et al. 2015) and the adequate number of zones is difficult to determine. Doherty (2003) suggested an alternative approach utilising pilot points. Instead of solving the inverse problem for a finite number of zones, pilot points covers the model domain (with various intensity based on importance) and the model solves for parameters at these points. Interpolation is then done to extend parameterisation over the entire model area (Doherty 2003, 2005).

This study aims at understanding the general hydrogeology of Qatar aquifers through a robust calibrated model of the steady state conditions. This will help understand the natural flow regime and quantification of hydrogeological inputs and outputs prior to groundwater developments. The model will be later used for transient simulation of different artificial recharge scenarios. The calibrated model was achieved using 1500 pilot points for hydraulic conductivity and 500 points for aquifer recharge.

\section{The study area and geology}

Qatar is a small country located in the eastern part of the Arabian Peninsula and extending as a small peninsula in the Arabian Gulf. The total area of the country is around $11,586 \mathrm{~km}^{2}$ extending in the north south direction, as shown in Fig. 1. The country is surrounded by the sea from all direction but the south, where it borders Saudi Arabia.

As a result of rapid socio-economic development in Qatar over the last two decades, the population of the country has dramatically increased from less than 0.5 million inhabitants in 1995 to more than 2.3 million in 2014 (The World Bank Databank 2015; United nations 2014). This sharp jump in population put the resources of the country under pressure, including among other things, water resources.

Topography of the country is characterized by low relief except in some places in the south where the topography is slightly high. The land surface elevations vary from 0 near the shoreline to around 107 meters above mean sea level in some places, as shown in Fig. 1.

The country relies on desalination to meet its growing demand for water. Agricultural farms are clustered mainly in the northern part of the country, where some fresh groundwater exists. In the south, the quality of groundwater is generally poor and not suitable for irrigation (Eccleston et al. 1981).

Geology of Qatar comprises mainly limestone layers with dolomite from Neogene period (Eocene and Miocene epoch). Some Quaternary deposits such as beach deposits and sabkha formations (evaporites) occurs along the coast line (Fig. 2). Qatar Arch is the major geological anticline located in the middle of the country along the north-south direction. Another smaller anticline is located in the west (Dukhan anticline). In general, the geology can be divided into three layers, namely from top to bottom: (1) Dam and Dammam Formation, (2) Russ Formation and (3) Umm AL-Radhuma Formation.

The upper layer (Dam and Dammam) covers the majority of the country surface and composed of limestone with dolomite from middle Miocene and middle Eocene. The upper layer is called locally Simsima limestone. Some shale sediments occur in this limestone. The total thickness of this layer is less than $50 \mathrm{~m}$.

The middle layer (Russ formation) is located underneath Dam and Dammam Formation and only exposed to the surface in a smaller area in the northern part of the country, as a result of erosion of the upper layer. It is composed of chalky limestone from lower Eocene, and contains a layer of shale in the southern part of the country. A gypsum bed occurs within this formation, especially in the southern part of the country, which affects the water quality. Russ formation is thicker than the upper one, with a thickness up to $90 \mathrm{~m}$.

The lower layer (Umm Al-Radhuma Formation) is the lowest and thickest layer in the Tertiary geology of Qatar. It comprises chalky and dolomitic limestone from Palaeocene. The thickness of this layer is more than $300 \mathrm{~m}$ and outcrops in the eastern Saudi Arabia, where it receives rainfall recharge.

The geology of Qatar is characterized by sinkholes and land depressions (Sadiq and Nasir 2002; Eccleston et al. 1981). Many caves and channels exist in the karst 


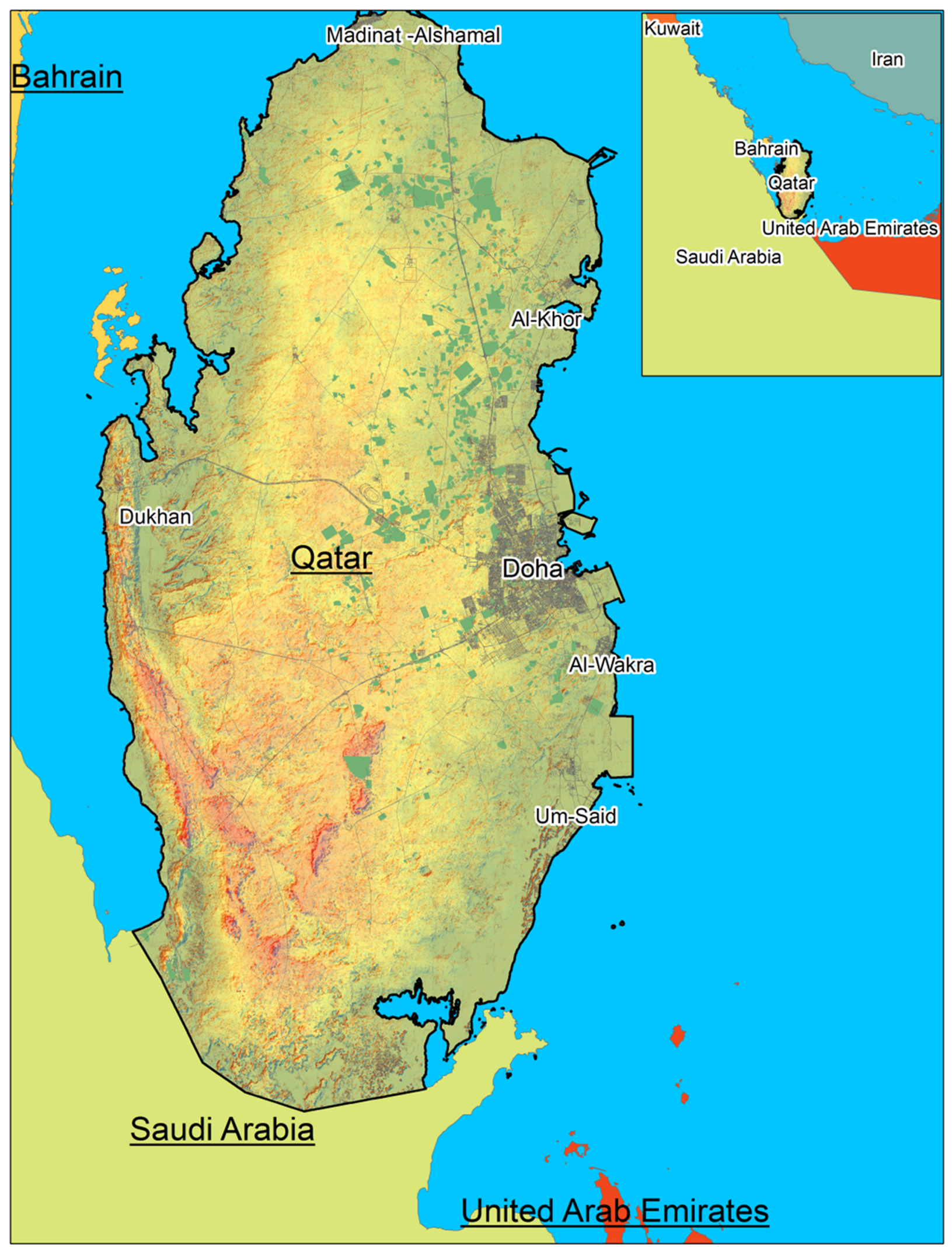

Fig. 1 Location map of Qatar and a regional map (inset) 


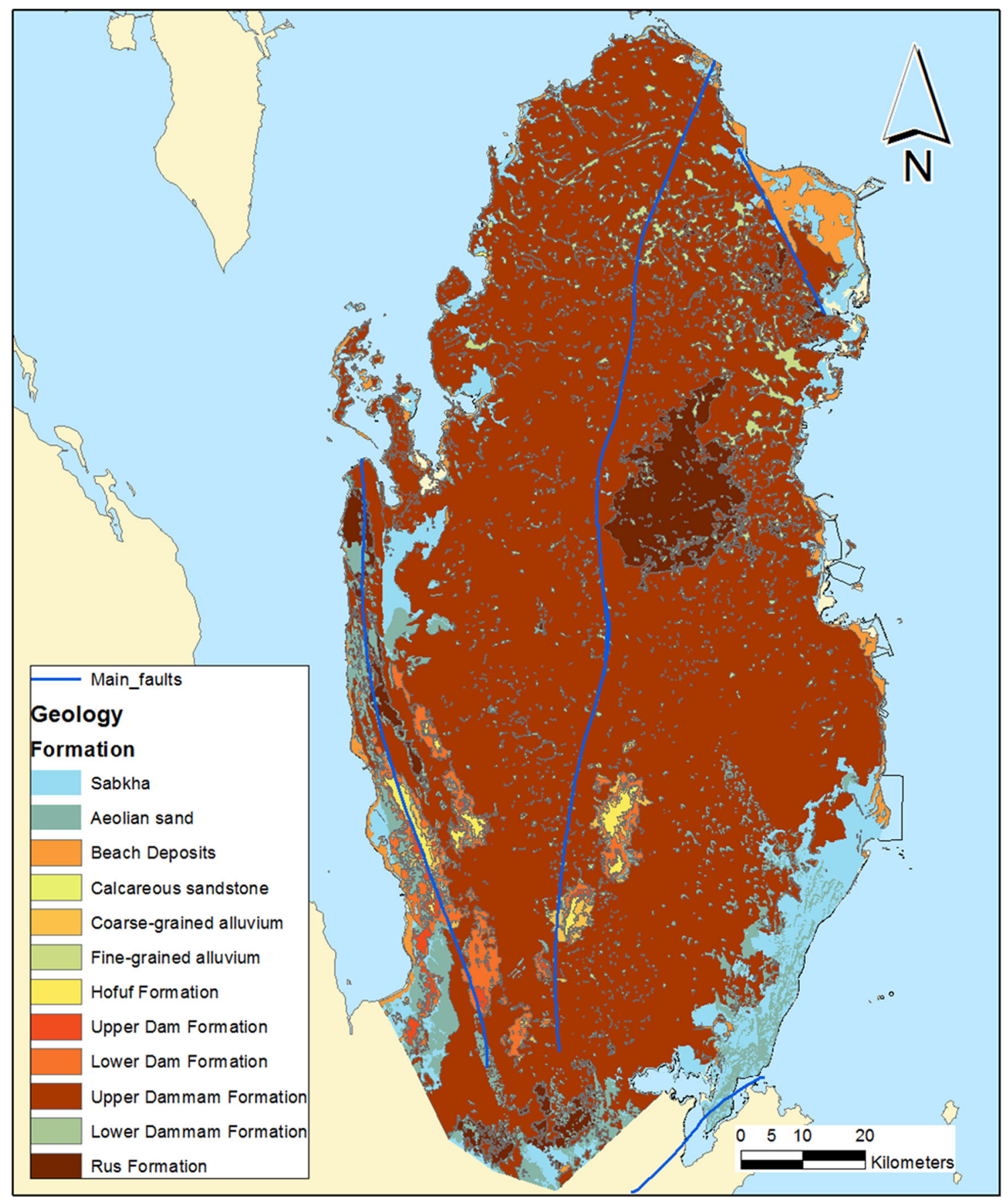

Fig. 2 Surface geology of Qatar

carbonate aquifers resulted from dissolution of limestone. As a result, hydraulic properties are highly heterogeneous.

Groundwater occurs as fresh lenses situated atop of brackish and saline groundwater. The water quality has been deteriorating as a result of over-pumping and seawater intrusion. Comparison of recent piezometric survey with historical ones reveals a water table drop of more than $10 \mathrm{~m}$ in some places (Schlumberger Water Services 2009 b). Aquifers are recharged locally by rainfall, which is very little and erratic. The average annual rainfall is $80 \mathrm{~mm}$ per year with spatial variation between $50 \mathrm{~mm}$ in the south to more than $100 \mathrm{~mm}$ in the north (Alsharhan et al. 2001). In a storm event, rainfall runoff accumulate in land depression, which are scattered in the country, and ultimately recharging the aquifer. These land depressions vary in size from a few meters in diameters to more than $5 \mathrm{~km}$, and are a result of land collapse due to karst nature of limestone. Deep aquifers receive lateral regional flows as 
Table 1 Recharge estimation from different studies

\begin{tabular}{lll}
\hline Reference & $\begin{array}{l}\text { Recharge values } \\
\text { (million } \mathrm{m}^{3} / \text { years) }\end{array}$ & Remarks \\
\hline $\begin{array}{l}\text { Eccleston et al. (1981) } \\
\text { Lloyd et al. (1987) }\end{array}$ & 50 & Based on a percentage of rainfall \\
& 9.5 & $\begin{array}{l}\text { Only the northern part of the country using rainfall } \\
\text { runoff analysis }\end{array}$ \\
Pike (1985) & 20 & Based on water balance analysis \\
Harhash and Yousif (1985) & 41 & Based on data from 1962 to 1980 \\
Kimrey (1985) & 27 & Based on a rainfall percentage \\
Baalousha (2015) & 25 & Based on Piezometric contours \\
Schlumberger Water Services (2009a) & 56 & Long term average \\
Food and Agriculture Organisation of the United Nations & 56 & Long term average \\
$\quad$ FAO) (2015) & 89.4 & Rainfall-runoff analysis for the period 1994-2007 \\
Schlumberger Water Services (2009b) & &
\end{tabular}

they outcrop in the eastern Saudi Arabia. However, most of deep groundwater is connate with poor quality.

\section{Model development}

\section{Conceptual model and discretization}

The model consists of three layers representing from top to bottom Dam and Dammam Formation, Russ Formation and Umm Al-Radhuma Formation. Model boundaries are constant head from all direction bounded by the sea, but in the south it is head dependent-boundary. The steady state conditions were assumed in 1958, for which year the oldest piezometric survey data is available (Al-Hajari 1990). At that time, abstraction was assumed to be minimal as the population of the country was very low. The water table occurs in the top layer only in the low lands areas such as coastal areas but otherwise in the middle layer.

The model covers the entire country of $11,500 \mathrm{~km}^{2}$ and was discretized to 500 by $500 \mathrm{~m}$ cells. The finite difference grid consists of 208 columns and 390 rows; hence the total number of cells in each layer of the model is 81120 . Structural contours of different geological layers were digitized and a 3D geological model was created and used for this model.

The USGS finite difference-based MODFLOW (Harbaugh et al. 2000) was used to simulate the groundwater flow in this study.

\section{Hydraulic properties}

Given the karst nature of the aquifer, it is highly heterogeneous. Aquifer tests results were carried out and documented in many studies (Eccleston et al. 1981; Schlumberger Water

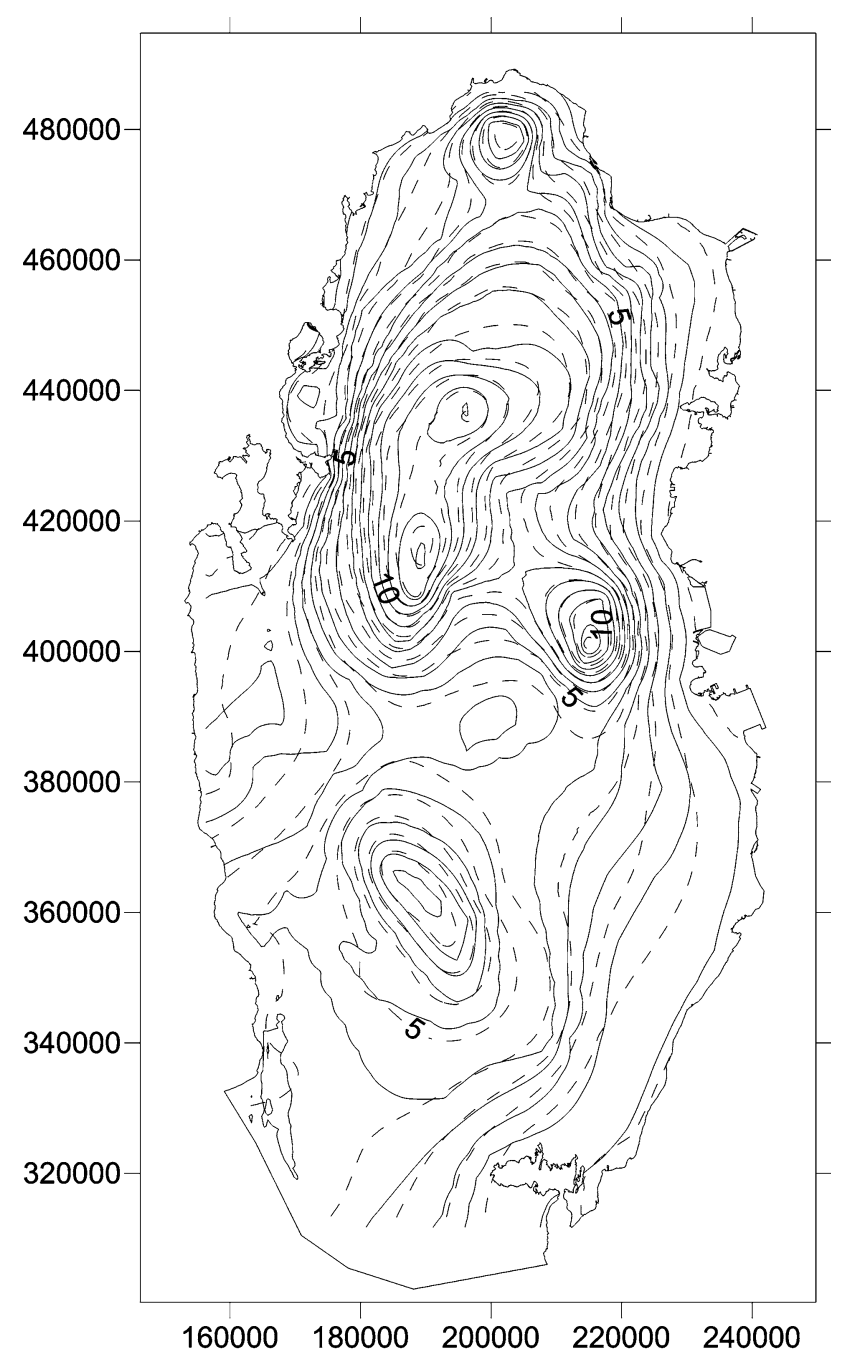

Fig. 3 Measured head (1958-1972-) shown as solid lines and calibrated head (dashed line) 
Services 2009a). Ecclston et al. (1981) pumping test results of the shallow aquifer show the transmissivity varies between 156 and $312 \mathrm{~m}^{2} /$ days, which is corresponding to hydraulic conductivity values of 15 to $30 \mathrm{~m} /$ day. The transmissivity of Rus aquifer has a higher variability, as it varies between 2 and $714 \mathrm{~m}^{2} /$ day (Eccleston et al. 1981). The deeper aquifer (Umm Al-Radhuma) has a transmissivity values between 286 and $3160 \mathrm{~m}^{2} /$ days. In general, the overall hydraulic conductivities for all aquifers vary between 4 and more than $1000 \mathrm{~m} /$ day, based on Eccleston et al. (1981).

Schlumberger Water Services carried out 13 pumping test in the entire country. Results show that transmissivity varies between 20 to more than $1000 \mathrm{~m}^{2} /$ day in the north. The situation in the south is totally different as the transmissivity is as low as $2.6 \mathrm{~m}^{2} /$ day (Schlumberger Water Services 2009a).

More recent data from aquifer testing for rail project within Doha City showed the hydraulic conductivity varies between 0.01 to $530 \mathrm{~m} /$ day (Schlumberger Water Services 2013).

In general, all aquifer tests results show higher transmissivity in the northern part of the country and lower in the south. This is consistent with the geological settings of the country, where more karst and land depressions occur in the north.

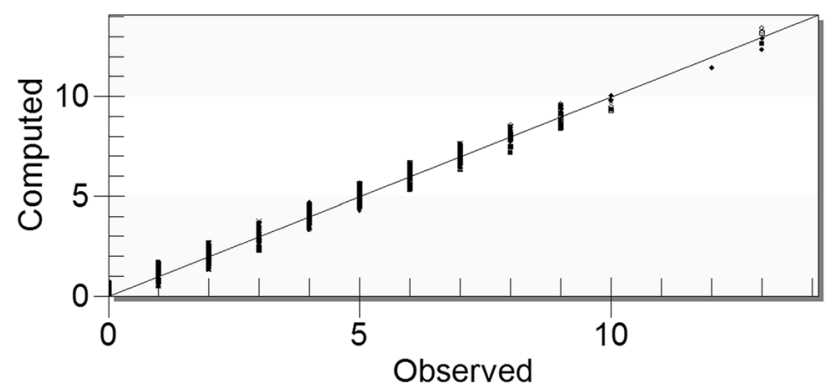

Fig. 4 Observed versus computed head
In this study, most recent data of aquifer test have been used to parameterize the model for the first run. Then the hydraulic conductivity in all layers was calibrated.

\section{Natural recharge}

Despite the arid conditions of the country and scarcity of rainfall, natural recharge occurs, especially in the northern part of the country where surface runoff derives storm water into land depressions. Historical groundwater piezometric maps (Al-Hajari 1990) show mounds in the northern and central parts of the country, which are clear indications of surface recharge. Many studies were done to estimate natural recharge (Eccleston et al. 1981; Lloyd et al. 1987; Food and Agriculture Organisation of the United Nations (FAO) 2015; Schlumberger Water Services 2009a; Baalousha 2015). Table 1 below summarizes the recharge estimation results from different sources.

The spatial distribution of rainfall recharge was based on Baalousha (2015) and then calibrated separately from hydraulic conductivity. In addition to natural recharge from rainfall, little lateral groundwater flow comes from Saudi Arabia through the southern border. However, this flow was estimated at 1 million $\mathrm{m}^{3}$ per year (Food and Agriculture Organisation of the United Nations (FAO) (2015). General-Head Boundary package in Modflow was used to simulate this lateral inflow.

\section{Model calibration}

The main challenge facing regional scale model development-as is the case with Qatar model- is the calibration process. Calibration is the process of minimization the difference between model results and field measurements. In

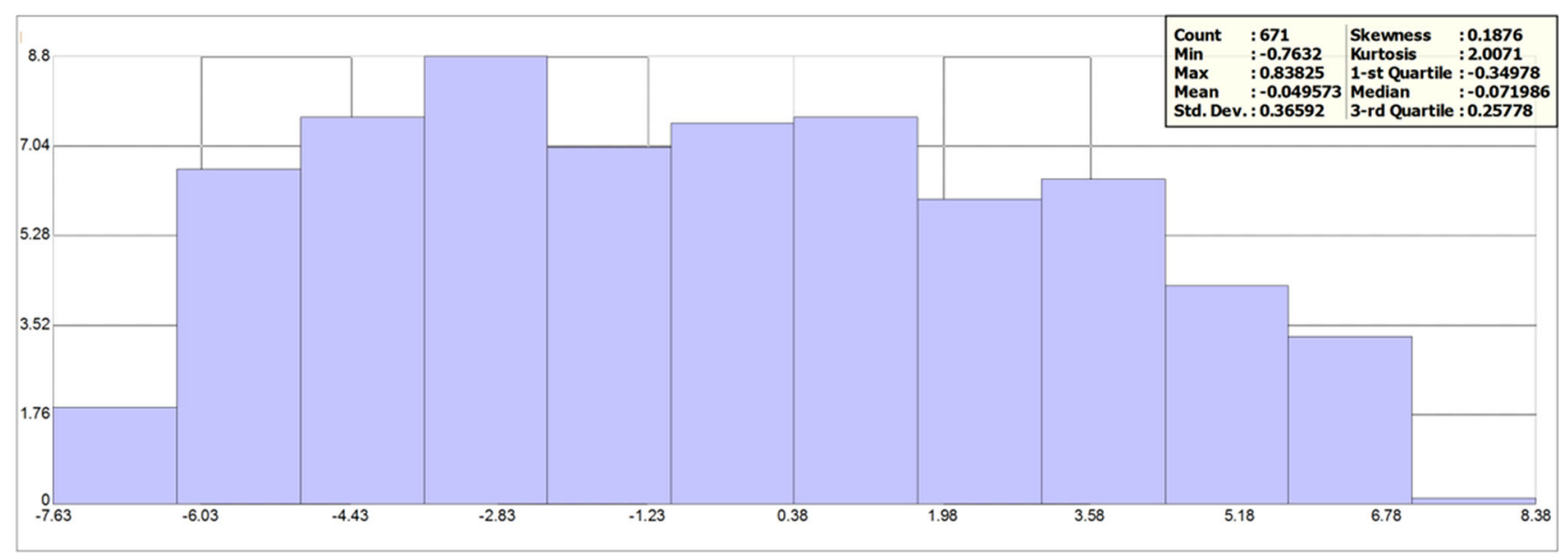

Fig. 5 Residual error histogram 
this case, uncertain parameters like hydraulic conductivity and groundwater recharge are being changed to reduce this difference. Pilot points method was used for the calibration, instead of zonation approach. The later method requires division of the model domain into a number of zones where the calibrated parameters do not change within each. Zonation approach over-simplifies parameters (Doherty and Hunt 2010) and imposes prior information on the parameter estimation process. The abrupt change between different zones is not realistic and not well-supported by field data (Anderson et al. 2015). Construction of zones and the variation between them is always questionable.

Pilot points method is a middle way between the entire domain parameterization (i.e. one parameter at each cell) and the zonation approach. They are a set of points in the model domain at which the model estimates values of a calibrated parameter/s. Interpolation using kriging or any other method is used to estimate the calibrated parameter in the entire model domain (Doherty and Hunt 2010). This way, the pilot points smoothen parameter variation within the model domain and overcomes the zonation approach limitation, but at a cost. As the number of pilot points increases, it becomes larger than observations. This is problematic as the solution becomes unstable and nonunique (Doherty 2003). In addition, as the number of pilot points increases, the number of required model runs increases. To overcome these problems regularization was used. Regularization adds prior information to the inverse problem and helps stabilize the solution and more parameters than observations can be estimated (Doherty 2003; Doherty et al. 2010). By adding more information to the inverse modelling, the highly parameterized calibration process will overcome the ill-posed problem (Anderson et al. 2015).

The inverse problem was run using Model-Independent Parameter Estimation and Uncertainty Analysis (PEST) (Doherty 2005). Two different types of regularization are available in PEST: Singular Value Decomposition (SVD) and Tikhonov regularization (Doherty 2005). SVD is a method to reduce the process matrices into a smaller number of parameters called subset. This is done by first running the model with all pilot points to get the sensitivity matrix (Jacobian) and then parameters that deemed not affecting model results are dropped. The result is a much smaller and computationally less expensive problem. Tikhonov regularization is based on the assumption that the objective function of the inverse problem has two components: one is based on hard knowledge and the other is based on soft knowledge (Doherty 2003). Detailed discussion of mathematical formulation of regularizations is beyond the scope of this study, but more details can be found in Doherty $(2003,2005)$ and Anderson et al. (2015). A total of 1500 pilot points covering the three layers of the model domain were used (20 in the x-direction and 25 points in the y-direction in each layer). SVD regularization was used in this study, and thus the total number of parameters was significantly reduced.

Recharge was first calibrated and then the hydraulic conductivity of the three model layers. The separation of calibration process was to eliminate the effect of any correlation between hydraulic conductivity and rainfall recharge.

Table 2 Calibrated water balance

\begin{tabular}{lcc}
\hline Component & $\begin{array}{l}\text { Inflow } \\
\left(\text { million } \mathrm{m}^{3}\right)\end{array}$ & $\begin{array}{l}\text { Outflow } \\
\left(\text { million } \mathrm{m}^{3}\right)\end{array}$ \\
\hline Rainfall recharge & 65.63 & 0 \\
Lateral inflow into the aquifer & 1.08 & 0 \\
Flow from/to the sea & 0.05 & 66.71 \\
Total & 66.76 & 66.71 \\
Discrepancy & $0.05(0.074 \%)$ & \\
\hline
\end{tabular}

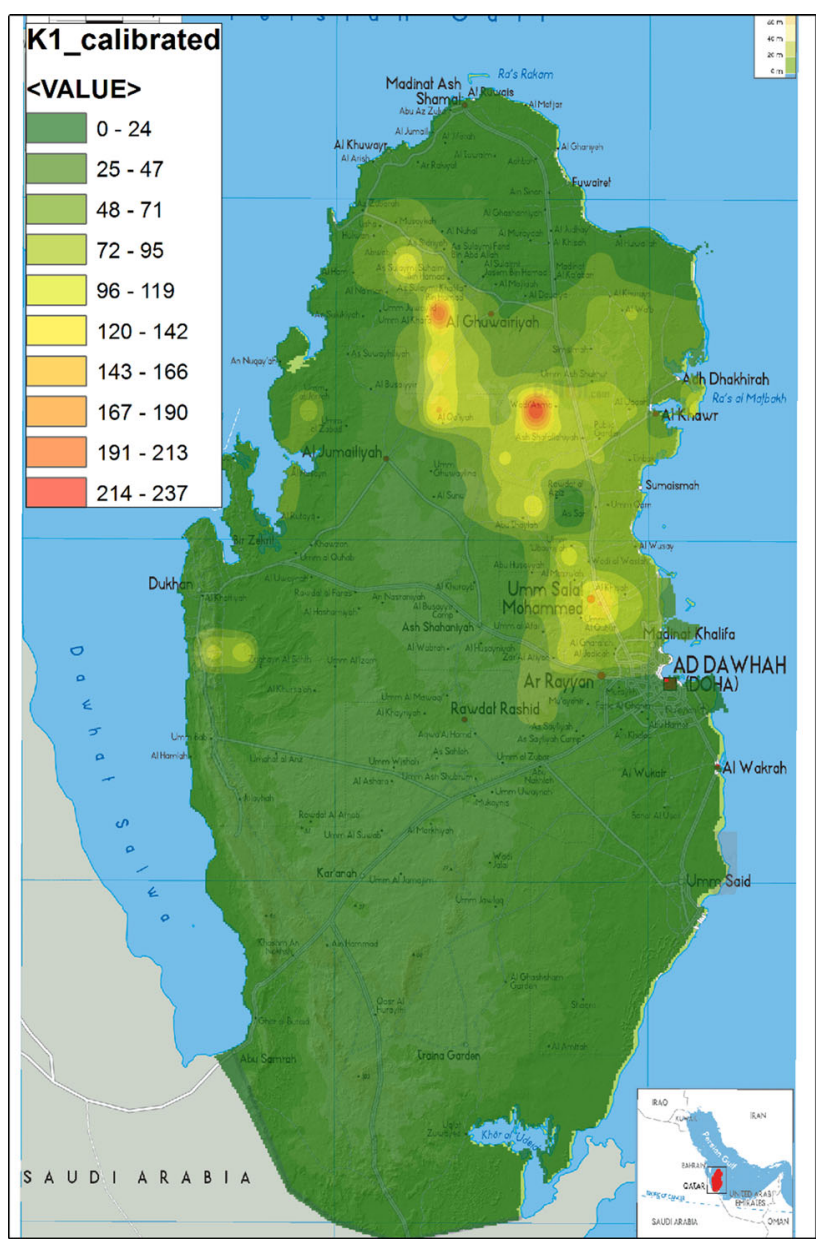

Fig. 6 Calibrated hydraulic conductivity of layer 1 (m/days) 


\section{Model results}

For steady state simulation, it is necessary to have observation data representing the natural conditions, where human interference is minimal or absent. The oldest available data for groundwater level is from the year 1958 (Al-Hajari 1990), which covers half of the country. Digitizing of the 1958 contour map was done to obtain raw data of groundwater level. In areas where data from 1958 was not available, data from 1972 was used. As a result, a total of 672 observation points covering the entire model domain where obtained. The total error in the calibration process was calculated as the sum of the difference between modelled and measured values of groundwater level, which is equal to $33 \mathrm{~m}$. The root mean square error is $91.4 \mathrm{~m}$.

The calibrated model results show that the first layer is dry except in low land areas (i.e. coastal areas) as the water table occurs below this layer. Figure 3 shows the modelled groundwater head draped over observed head of the year 1958-1972. Obviously, there is a good match between the observation level and the simulation results. It should be

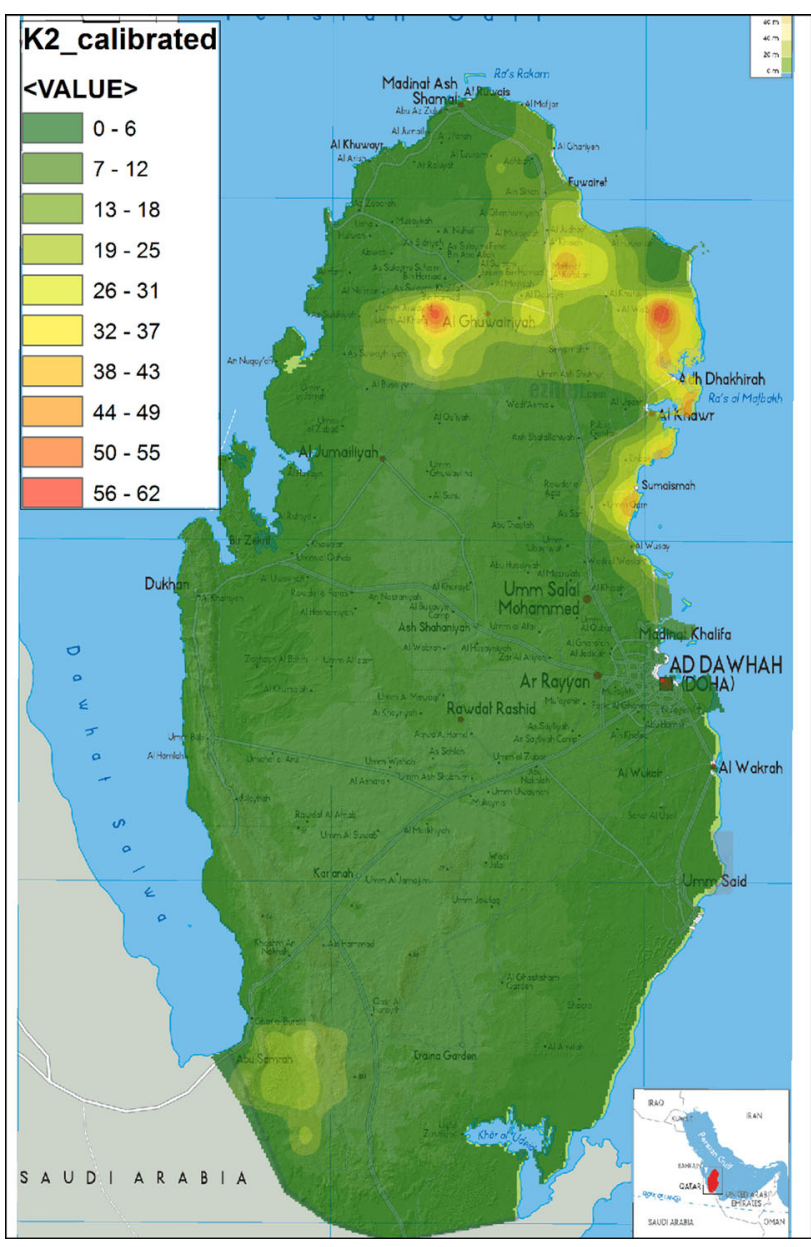

Fig. 7 Calibrated hydraulic conductivity of layer 2 (m/days) noted the observed head was interpolated to cover the entire domain of the model as some areas, especially in the south, are not well covered by piezometric data.

Figure 4 shows computed versus observed heads for all observation points. Except for one single point, the all 672 remaining points are distributed at both sides of the line $(y=x)$ in the figure, which means the error is not biased.

Residual error histogram is depicted in Fig. 5. For unbiased calibration, the mean value of the residual error should be as close as possible to 0 and the error is distributed around the mean. As shown on the figure, the mean value of the residual error is 0.049 , which is close to 0 and distributed at either sides of the mean.

The calibrated water balance is shown in Table 2. The main input into the aquifer is rainfall recharge, which amounts to 65.63 million $\mathrm{m}^{3}$ per year. This value is comparable to previous studies estimation, as presented in Table 1. The lateral groundwater inflow into Qatar (through the southern border with Saudi Arabia) is 1.08 million $\mathrm{m}^{3}$ per year, which is similar to the estimation of Food and Agricultural Organization of the United Nations

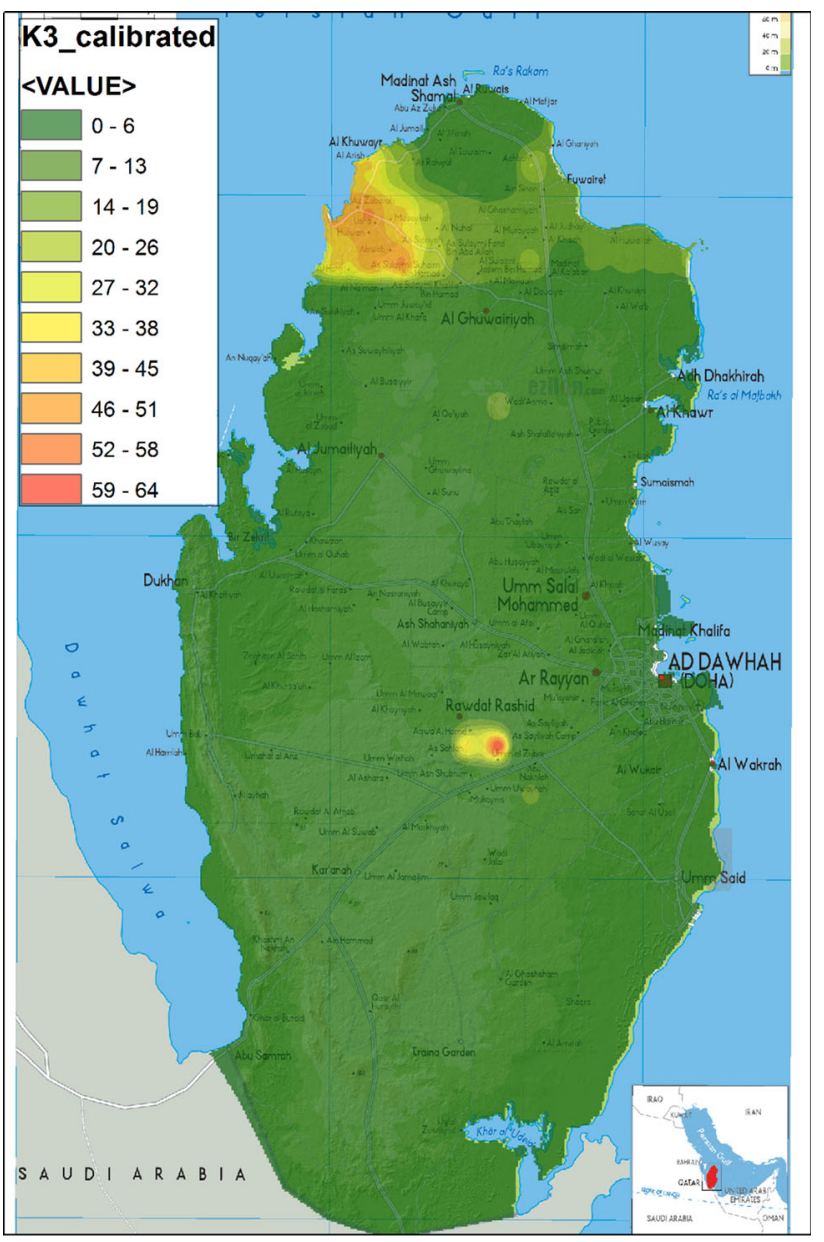

Fig. 8 Calibrated hydraulic conductivity of layer 3 (m/days) 
(2014). It is noted that the seawater intrusion at that time was as little as 0.05 million $\mathrm{m}^{3}$ per year. The overall discrepancy in water budget is 0.05 million $\mathrm{m}^{3}$ per year or $0.074 \%$ of the total budget.

\section{Calibrated hydraulic conductivity}

Figures 6, 7, and 8 show the spatial distribution of calibrated hydraulic conductivities for layers 1-3, respectively. Values of hydraulic conductivities vary from (close to 0 ) to more than $200 \mathrm{~m} /$ day. The top layer shows higher values compared to the lower ones. It is also noted the higher values of hydraulic conductivity occur in the northern part of the country. This is consistent with the most recent aquifer test data (Schlumberger Water Services 2009a).

\section{Calibrated rainfall recharge}

Figure 9 shows the calibrated recharge values, which vary between 0 and $1.16 \mathrm{~mm} /$ day. Obviously, the high recharge areas occurred in the northern part of the country, which is consistent with previous studies (i.e. Eccleston et al. 1981) and also with rainfall distribution.

\section{Conclusions}

This study outlines model development and calibration of the steady state groundwater flow model for Qatar. This work was initiated as a fundamental step to understand the natural status of the aquifer system in Qatar and to help establish aquifer storage and recovery scheme. In addition,
Fig. 9 Calibrated rainfall recharge $(\mathrm{m} /$ day $)$

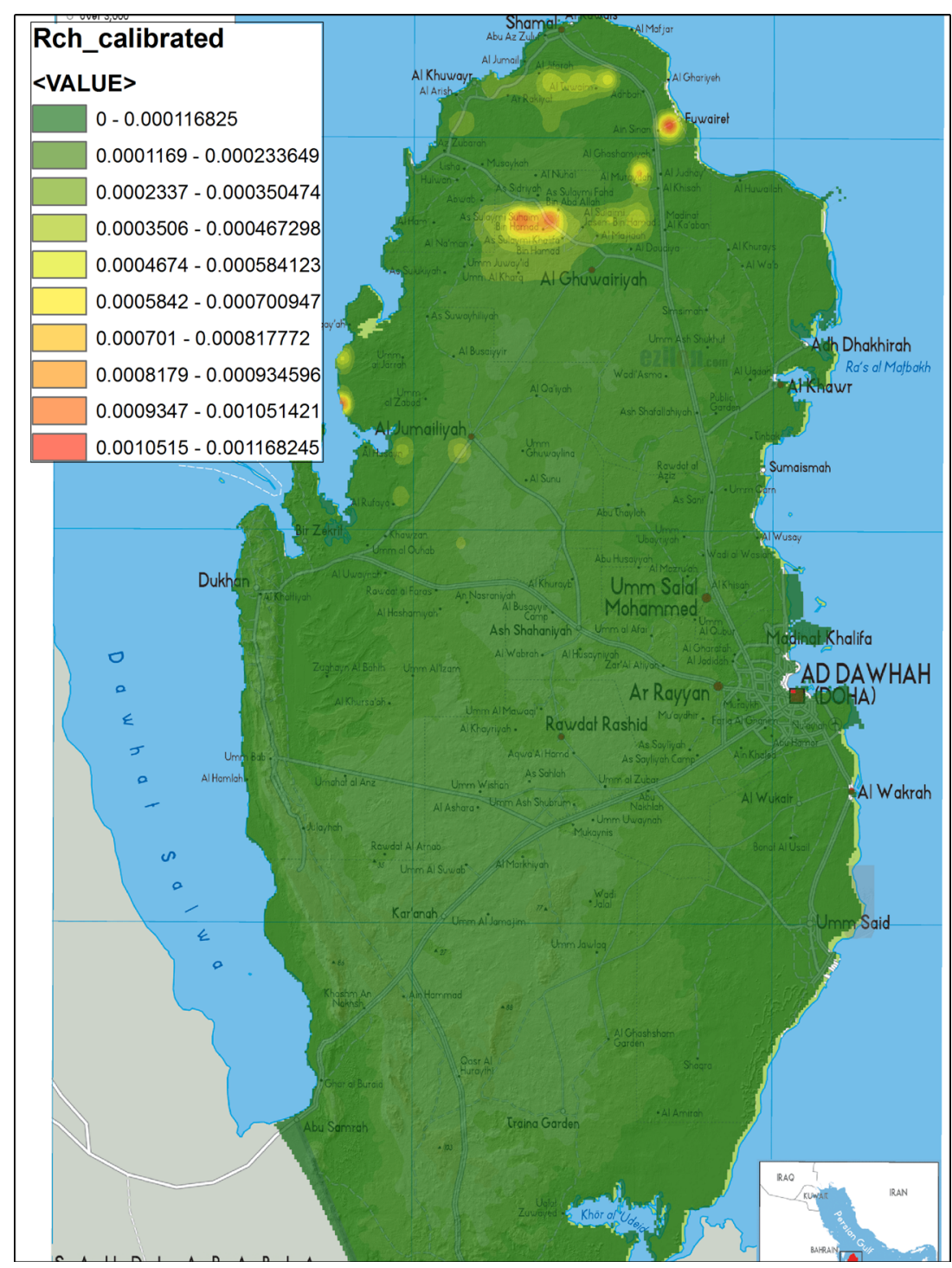


the outcome of the model is the basis for a transient flow model, solute transport and predictive modelling.

As the model covers the entire country (more than $11,500 \mathrm{~km}^{2}$ ), and since the aquifer contains karst features, calibration process was not an easy task. Using pilot points with regularization made it possible to smoothly calibrate the model and to reproduce the historical groundwater levels of 1958. It was possible to calibrate this regional model with 1500 pilot points (500 for each model layer) with no difficulties because of using regularization. Pilot points with regularization eliminate the difficulties associated with the classical zonation approach.

Results show the natural groundwater recharge is approximately 66 million $\mathrm{m}^{3}$ per year. This is similar to or in the range of results found in the literature. Also this result highlights the urgent need for artificial recharge as the current groundwater abstraction is 250 million $\mathrm{m}^{3}$ (Schlumberger Water Services 2009a), which is more than three folds of natural recharge. The calibrated spatial distribution of groundwater recharge shows recharge is concentrated more in the northern part of the country, which is consistent with the hydrogeological settings and rainfall distribution.

Knowledge of spatial variability of hydraulic conductivity is very important for the implementation of aquifer storage and recovery. Calibration results show the spatial distribution of hydraulic conductivity for the three model layers. High hydraulic conductivity in general occurs in the northern part of the country, where limestone is highly fractured.

\section{References}

Al-Hajari S (1990) Geology of the Tertiary and its influence on the Aquifer system of Qatar and Eastern Arabia. PhD Dissertation. University Microfilms International

Alsharhan AS, Rizk ZA, Nairn AEM, Bakhit DW, Alhajari SA (2001) Hydrogeology of an arid region : the Arabian Gulf and adjoining areas. Elsevier

Anderson M, Woessner W, Hunt R (2015) Applied groundwater modeling. Simulation of flow and advective transport. Second Edition. Elsevier

Baalousha HM (2012a) Modelling surface-groundwater interaction in the Ruataniwha basin, Hawke's Bay, New Zealand. Environmental Earth Sciences May 2012, Volume 66, Issue 1, pp 285-294

Baalousha HM (2012b) Characterisation of groundwater-surface water interaction using field measurements and numerical modelling: a case study from the Ruataniwha Basin, Hawke's Bay, New Zealand. Applied Water Science June 2012, Volume 2 , Issue 2, pp 109-118

Baalousha H (2015) Estimation of natural groundwater recharge in Qatar using GIS. In: Weber T, McPhee MJ, Anderssen RS (eds) MODSIM2015, 21st International Congress on Modelling and Simulation. Modelling and Simulation Society of Australia and New Zealand, December 2015, pp. 2026-2032. ISBN: 978-0-
9872143-5-5. http://www.mssanz.org.au/modsim2015/L2/baa lousha.pdf

Doherty J (2003) Ground water model calibration using pilot points and regularization. Ground Water 41(2):170-177

Doherty J (2005) PEST Model-Independent parameter estimation user manual: 5th Edition. Watermark Numerical Computing. http:// www.pesthomepage.org/Downloads.php

Doherty JE, Hunt RJ (2010) Approaches to highly parameterized inversion: a guide to using PEST for groundwater-model calibration. U.S. Geological Survey Scientific Investigations Report 2010-5169, p 59

Doherty JE, Fienen MN, Hunt RJ (2010) Approaches to highly parameterized inversion: pilot-point theory guidelines, and research directions. U.S. Geological Survey Scientific Investigations Report 2010-5168, p 36

Eccleston BL, Pike JG, Harhash I (1981) The water resources in Qatar and their development. Food and Agricultural Organization of the United Nations

Food and Agriculture Organisation of the United Nations (FAO) (2015) AQUASTAT global water information system. http:// www.fao.org/nr/water/aquastat/main/index.stm. Last accessed October 2015

General Secretariat for Development Planning (GSDP) (2008) Qatar National Vision 2030. http://www.mdps.gov.qa/portal/page/por tal/gsdp_en/qatar_national_vision/qnv_2030_document/QNV20 30_English_v2.pdf. Last visited January 2016

Harhash IE, Yousif AM (1985) Groundwater in Qatar, summary of hydrological studies and results. Department of Agriculture and Water Research, Ministry of Industry and Agriculture, State of Qatar

Harbaugh AW, Banta ER, Hill MC, McDonald MG (2000) MODFLOW-2000, The U.S. Geological survey modular ground-water model-user guide to modularization concepts and the groundwater flow process: U.S. Geological Survey Open-File Report 00-92, $121 \mathrm{p}$

http://unstats.un.org/unsd/demographic/products/dyb/dybsets/2014.pdf

Kimrey J (1985) Proposed artificial recharge studies in northern Qatar. United States Department of the Interior Geological Survey. Open file report 85-343

Lloyd JW, Pike JG, Eccleston BL, Chidley TRE (1987) The hydrogeology of complex lens conditions in Qatar. J Hydrol $89: 239-258$

Pike JG (1985) Groundwater resources and development in the central region of the Arabian Gulf. In: Memoirs of 18th Congress. IAH Hydrogeology in the Service of Man, Cambridge, pp 46-55

Qatar General Electricity and Water Corporation (Kahramaa) (2014) Sustainability Report 2013. http://www.km.com.qa

Rahman Md. M, Shahid S (2004) Modeling groundwater flow for the delineation of wellhead protection area around a water-well at Nachole of Bangladesh. J Spatial Hydrol 4(1)

Sadiq AM, Nasir SJ (2002) Middle Pleistocene karst evolution in the State of Qatar, Arabian Gulf. J Cave Karst Stud 64(2):132-139

Schlumberger Water Services (2009a). Studying and developing the natural and artificial recharge of the groundwater in aquifer in the State of Qatar. Project final report

Schlumberger Water Services (2009b). Studying and developing the natural and artificial recharge of the groundwater in aquifer in the State of Qatar. Study No.1 Build a surface rainfall-runoff model to study the relation between rainfall, runoff and recharge. Final Report

Schlumberger Water Services (2013) Qatar Integrated Railways Project Priority Metro Network-Phase 1 Underground Metro Lines Regional Groundwater Model Report

The World Bank Databank (2015) http://data.worldbank.org/country/ qatar. Last accessed October 2015 
United Nations (2014) United Nations Demographic Book. Department of Economic and Social Affairs. ST/ESA/STAT/SER.R/44

Wang T, Franz TE, Yue W, Szilagyi J, Zlotnik V, You J, Chen X, Shulski MD, Young A (2016) Feasibility analysis of using inverse modeling for estimating natural groundwater recharge from a large-scale soil moisture monitoring network. J Hydrol 533:250-265. doi:10.1016/j.jhydrol.2015.12.019 